\title{
Prophylaxis of migraine with aura: a place for acetylsalicylic acid
}

\author{
LT Savi $^{*}$, V Condello ${ }^{1}$, F Bert $^{2}$, L Pinessi $^{3}$ \\ From The European Headache and Migraine Trust International Congress \\ London, UK. 20-23 September 2012
}

\begin{abstract}
Aim
Aim of our study was to assess the efficacy and tolerability of Acetylsalicylic acid (ASA) in migraine with aura (MA) management, in a sample afferent to the Headache Centre of San Giovanni Battista University-Hospital of Torino.

\section{Materials and methods}

We analyzed the medical records of 196 patients affering consecutively to our Centre between 1995 and 2007 and receiving a prophylactic treatment, dividing them in two groups: the ones receiving ASA (90) and those who were treated with other therapies (106). Primary endpoint was to evaluate the improvement in MA crisis frequency in the two groups. A binary logistic regression model was used to identify possible factors associated with the positive response to treatment.
\end{abstract}

\section{Results}

The mean age was $32.1( \pm 9.9)$ in ASA group and 36.8 $( \pm 14.9)$ in no-ASA group. Positive response to treatment (measured as a reduction of at least the $50 \%$ of crisis with aura) was reported by $85.6 \%$ of patients in the ASA group and $51.9 \%$ in the control group $(\mathrm{p}<0.001)$. Multivariate analysis showed, as only variable related with a positive response to treatment, the group (ASA Group: OR 6.26, $p=0.006$ ), while there were no relationships with gender, age or typology of aura.

\section{Discussion}

In the past, other studies compared the effectiveness of ASA in migraine versus other prophylactic therapies, but they often considered very small samples, mixing $\mathrm{MA}$ and migraine without aura (MoA) together. In those setting ASA appeared to be mildly effective. Our results show a large positive response to the treatment

Headache Centre, Italy

Full list of author information is available at the end of the article with Acetylsalicylic acid, whose probability of success was about six times greater than the one associated with other therapies.

\section{Conclusions}

According to our results, asa is not only effective in the majority of MA cases, but the response is usually evident in a short time. A double blind study with a larger sample is needed to ascertain these findings.

\section{Author details}

${ }^{1}$ Headache Centre, Italy. ${ }^{2}$ Department of Public Health, Italy. ${ }^{3}$ University of Turin, Italy.

Published: 21 February 2013

doi:10.1186/1129-2377-14-S1-P195

Cite this article as: Savi et al:: Prophylaxis of migraine with aura: a place for acetylsalicylic acid. The Journal of Headache and Pain 2013 14(Suppl 1): P195.

\section{SpringerOpen ${ }^{\circ}$}

(C) 2013 Savi et al; licensee Springer. This is an Open Access article distributed under the terms of the Creative Commons Attribution License (http://creativecommons.org/licenses/by/2.0), which permits unrestricted use, distribution, and reproduction in any medium, provided the original work is properly cited.
Submit your manuscript to a SpringerOpen ${ }^{\circ}$ journal and benefit from:

- Convenient online submission

- Rigorous peer review

- Immediate publication on acceptance

- Open access: articles freely available online

- High visibility within the field

- Retaining the copyright to your article

Submit your next manuscript at $>$ springeropen.com 